\title{
PENGARUH TERAPI N-ASETIL SISTEIN TERHADAP EKSPRESI INTERLEUKIN 17 DAN FIBROSIS INTERSTISIAL PADA MENCIT NEFRITIS LUPUS
}

\author{
THE EFFECT OF ACETYLCYSTEINE THERAPY ON INTERLEUKIN 17 \\ EXPRESSION AND INTERSTISIAL FIBROSIS ON NEPHRITIS LUPUS MICE \\ MODEL
}

\author{
Warigit Dri Atmoko, Bambang Purwanto, Sugiarto \\ Program Pendidikan Spesialis I Ilmu Penyakit Dalam Fakultas Kedokteran, \\ Universitas Sebelas Maret Surakarta. \\ Korespondensi: dr. Warigit Dri Atmoko, Sp. PD. Email: drwarigit@gmail.com
}

\begin{abstract}
ABSTRAK
Lupus nefritis (LN) terkait dengan penebalan membran basal glomerulus. Pengendapan kompleks imun memicu kaskade respon inflamasi disertai aktivasi reactive oxygen species (ROS), kemudian menyebabkan fibrosis yang mendorong terjadinya kerusakan ginjal. Interleukin 17 merupakan sitokin yang sangat berperan pada reaksi inflamasi tipe-lambat. Produksinya dipicu oleh peningkatan produksi kemokin oleh sejumlah jaringan untuk merekrut monosit dan netrofil ke sisi inflamasi. IL-17 diproduksi sel Th17 dan diinduksi oleh IL-23. IL-17 berespon terhadap invasi patogen ekstraseluler dan menginduksi perusakan matriks seluler patogen. IL-17 akan merangsang sel B untuk memproduksi dan mensekresikan autoantibodi, selanjutnya akan terbentuk kompleks atigen-autoantibodi. Kompleks antigen-autoantibodi yang berada di sirkulasi akhirnya akan terdisposisi pada sel target, termasuk sel fibroblas, sel mesangial, podosit, sel tubulus dan sel endotel di glomerulus. Kompleks ini akan menyebabkan terjadinya glomerulosklerosis dan fibrosis interstisial pada ginjal, kemudian selanjutnya menyebabkan kerusakan pada ginjal dan terjadilah mikroalbuminuria. Disamping itu, akan terjadi disfungsi endotel kapiler glomerulus yang akan menyebabkan albuminuria. Suplemen N-asetil sistein (NAS) pada lupus nefritis dapat mengurangi efek nefrotoksik pada ginjal, melalui penurunan ekspresi IL-17 dan derajat fibrosis interstisial. Penelitian ini merupakan penelitian eksperimental laboratoris, dengan sampel 24 ekor mencit Balb/C betina yang dibagi menjadi kelompok kontrol, LN, dan LN+NAS. Untuk membuat model LN, hewan coba diberikan injeksi $0,5 \mathrm{ml}$ pristan intraperitoneal dosis tunggal. NAS diberikan secara peroral dengan dosis $4,7 \mathrm{mg} / \mathrm{hari}$ (setara dengan dosis manusia $1.800 \mathrm{mg}$ ) selama delapan minggu. Ekspresi IL-17 diperiksa secara imunohistokimia dengan antibodi monoklonal terhadap IL-17. Cara ukur dinilai secara kuantitatif, dihitung jumlah sel positif IL17 terhadap $100 \mathrm{sel}$, secara visual dengan mikroskop cahaya pembesaran $400 \mathrm{x}$. Penilaian fibrosis interstisial ditentukan secara kuantitatif dengan cara mengukur tebal jaringan interstisial dengan menggunakan mikrometer yang telah dikalibrasi pada pembesaran $400 \mathrm{x}$. Analisis data menggunakan analysis of variance (Anova) dan untuk menentukan perbedaan kemaknaan digunakan $\mathrm{p}<0,05$. Hasil Penelitian menunjukkan bahwa pemberian NAS menurunkan ekspresi IL-17 (23,8 $\pm 14,1$ vs $10,6 \pm 6,8$ per 100 sel netrofil imunoreaktif; $p=0,042)$ dan menurunkan fibrosis interstisial $(22,3 \pm 5,7$ vs $15,5 \pm 5,4 ; \mathrm{p}=0,030)$ dibandingkan kelompok LN. Berdasarkan penelitian ini dapat disimpilkan bahwa NAS secara bermakna menurunkan ekspresi IL-17 dan fibrosis interstisial ginjal pada mencit model LN.
\end{abstract}

Kata Kunci: fibrosis interstisial, lupus nefritis, interleukin 17, pristan

\begin{abstract}
Lupus nephritis (LN) is associated with thickening of the glomerular basement membrane. The precipitation of the immune complex triggers a cascade of inflammatory responses with activation of reactive oxygen species (ROS), then causes fibrosis that promotes kidney damage. Interleukin 17 is a cytokine that plays a role in slowtype inflammatory reactions. Its production is triggered by an increase in chemokine production by a number of tissues to recruit monocytes and neutrophils to the inflammatory side. IL-17 produced Th17 cells and was induced by IL-23. IL-17 responds to the invasion of extracellular pathogens and induces the destruction of the cellular matrix of pathogens. IL-17 will stimulate B cells to produce and secrete autoantibodies, then form the complex of atigen-autoantibodi. The antigens-autoantibodies complex in the circulation will eventually be disposed in target
\end{abstract}


cells, including fibroblast cells, mesangial cells, podocytes, tubular cells and endothelial cells in the glomerulus. This complex will cause glomerulosclerosis and interstitial fibrosis of the kidney, then subsequently cause damage to the kidneys and microalbuminuria occurs. In addition, glomerular capillary endothelial dysfunction will result in albuminuria. $N$-acetyl cysteine (NAS) supplementation in lupus nephritis can reduce nephrotoxic effects on the kidney, through decreased IL-17 expression and interstitial fibrosis degree. This study was a laboratory experimental study, with a sample of 24 Balb / C female mice divided into control groups, $L N$, and LN + NAS. To model LN, animals were given $0.5 \mathrm{ml}$ injection of single-dose intraperitoneal prills. NAS was administered orally at a dose of $4.7 \mathrm{mg}$ / day (equivalent to 1,800 $\mathrm{mg}$ of human dose) for eight weeks. The IL-17 expression was immunohistochemically examined with monoclonal antibodies against IL-17. Measurement was quantitatively assessed, counting the number of IL-17 positive cells to 100 cells, visually with a $400 \times$ magnification of light microscope. The assessment of interstitial fibrosis was determined quantitatively by measuring the thickness of the interstitial tissue by using a micrometer that has been calibrated at $400 x$ magnification. Data analysis using analysis of variance (Anova) and to determine the difference of significance used $p<0,05$. The results showed that NAS administration decreased IL-17 expression $(23.8 \pm 14.1 \mathrm{vs.} 10.6 \pm 6.8$ per 100 immunoreactive neutrophil cells, $p=0.042)$ and reduced interstitial fibrosis $(22.3 \pm 5.7 v$ s. $15.5 \pm 5.4, p=0.030)$ than the LN group. Based on this study it can be concluded that NAS significantly decreases IL-17 expression and renal interstitial fibrosis in LN model mice.

Keywords: interstitial fibrosis, lupus nephritis, interleukin 17, pristan

\section{PENDAHULUAN}

Lupus Eritematosus Sistemik (LES) dapat mempengaruhi banyak organ mulai dari ginjal, kulit, selaput jantung, paru-paru, sistem saraf dan lainnya. Lupus nefritis (LN) adalah gambaran potensial serius dari LES. Meskipun LES biasanya melalui siklus periode flare dan remisi, pasien sering akhirnya mengalami kematian akibat penyakit ginjal stadium terminal atau kerusakan kardiovaskular. LES ditandai oleh adanya berbagai autoantibodi yang dapat membentuk kompleks imun yang mengendap di ginjal, memberikan kontribusi besar terhadap patogenesis LN. Terjadinya LN diprakarsai oleh adanya peran kaskade komplemen, autoantibodi, intoleransi, dan cross-talk sistem imunitas adaptif dan bawaan, perekrutan sel inflamasi dan akhirnya terjadi fibrosis yang mendorong terjadinya kerusakan ginjal.

Pengendapan kompleks imun memicu kaskade respon inflamasi disertai aktivasi reactive oxygen species (ROS), yang memainkan peran penting dalam terjadinya injuri glomerulus akut dan kronis pada pasien LN. Lupus nefritis tampak jelas secara histologis pada kebanyakan pasien dengan LES, bahkan mereka yang tidak menunjukkan manifestasi klinis penyakit ginjal. Inflamasi ginjal adalah salah satu manifestasi yang paling parah dari LES dan ditandai oleh deposisi autoantibodi dan komplemen, produksi sitokin/ kemokin, aktivasi dan perekrutan sel-sel inflamasi, dan kerusakan mikrovaskuler dan parenkim di ginjal.

Prevalensi penyakit ginjal pada pasien LES bervariasi antara 31-65\%. Berdasarkan data dari Asia, keterlibatan renal berkisar antara 6-100\% secara keseluruhan (Isbagio, 2006), sedangkan hasil penelitian di RS dr Moewardi Surakarta gangguan fungsi ginjal ditemukan pada $68 \%$ penderita LES dan kelainan ini merupakan penyebab kematian yang paling banyak.

Predisposisi genetik, sitokin proinflamasi dan anti-inflamasi, autoantibodi, kelainan limfosit serta defek pada sistem komplemen semua memiliki peran dalam pengembangan LES. Di antara faktor-faktor ini, kontribusi autoantibodi dan penyimpangan limfosit sangat berperan dalam patogenesis penyakit ginjal pada SLE. Terdapat hubungan erat antara produksi autoantibodi dan kelainan pada subpopulasi limfosit. Selain itu, perubahan autoantibodi dan subset limfosit dapat mencerminkan aktivitas penyakit lupus nefritis dan menjadi target potensial terapi imunosupresif. Oleh karena itu, pemahaman autoantibodi nefritogenik dan subset limfosit akan membantu mengembangkan strategi baru untuk pemantauan aktivitas penyakit dan pengobatan lupus nephritis.

Injeksi Pristan akan mengaktivasi Nf$\mathrm{kB}$ dalam makrofag untuk mensekresikan dan mengekspresikan sitokin-sitokin proinflamasi (IL6 dan TNF- $\alpha$ ) serta faktor pertumbuhan (TGF- $\beta 1$ ). IL-6 dan TNF- $\alpha$ akan memicu sumsum tulang 
sehingga terjadi leukositosis. Leukositosis akan memperbanyak sel-sel polimorfonuklear (PMN) maupun monosit untuk bergerak menuju tempat lesi pada ginjal. IL-8 sebagai neutrophyl chemotatic factor (NCF), akan menarik PMN dalam sirkulasi mendekat permukaan endotel pembuluh darah ginjal. TGF- $\beta 1$ merupakan sitokin yang paling dominan berperan dalam menyebabkan terjadinya glomerulosklerosis maupun interstitisal fibrosis. TGF- $\beta 1$ akan merangsang reseptor membran sel fibroblast sehingga mengekspresikan kolagen tipe-I akibatnya terjadi interstisial fibrosis. Selain itu, TGF- $\beta 1$ juga akan merangsang reseptor membran sel mesangial sehingga mengekspresikan kolagen tipe-IV, yang mengakibatkan terjadinya glomerulosklerosis. Limfosit B memiliki efek pleiotropik dalam pengembangan $\mathrm{LN}$, termasuk pembentukan autoantibodi, sekresi sitokin proinflamasi dan anti-inflamasi, presentasi autoantigen daninfiltrasilangsungkeginjal. Rangsangan endotel oleh TNF $\alpha$ akan menyebabkan endotel meng-ekspresikan $e$-selektin yang diperlukan untuk mengikat PMN. PMN kemudian akan mengekspresikan MMP-9. MMP-9 selanjutnya mendegradasi kolagen yang diekspresikan oleh sel fibroblas maupun mesangial. Dalam keadaan normal sesuai dengan hukum homeostasis, terjadi keseimbangan pengaruh TGF- $\beta 1$ dan MMP9. TGF- $\beta 1$ juga menghambat ekspresi MMP-9 yang diekspresikan oleh PMN. Pada penelitian ini injeksi Pristan diharapkan akan menyebabkan TGF- $\beta 1$ lebih dominan daripada MMP-9, sehingga terjadi interstitial fibrosis maupun glomerulosklerosis. IL-1 $\beta$ akan merangsang endotel untuk mengekspresikan ICAM, selanjutnya ICAM akan mengikat monosit kemudian monosit akan masuk ke jaringan dan akan berubah menjadi makrofag. Makrofag yang bertambah banyak akan menyebabkan meningkatnya proses ekspresi sitokin yang berakibat pada bertambah beratnya fibrosis.

Prinsip dasar tujuan pengobatan lupus nefritis adalah menekan reaksi inflamasi lupus, memperbaiki fungsi ginjal atau setidaknya mempertahankan fungsi ginjal agar tidak menjadi penyakit ginjal stadium akhir dan menurunkan risiko penyakit ginjal kronis dan aterosklerosis dan konsekuensi metabolik. Medikamentosa berupa kortikosteroid dan agen imunosupresif, dialisis dapat dilakukan untuk mengontrol gejala gagal ginjal. Transplantasi ginjal juga direkomendasikan (pasien dengan lupus yang aktif tidak boleh dilakukan transplantasi ginjal).

Obat-obatan yang memiliki efek seperti ROS scavenging, dan penghambatan jalur NF- $\kappa B$ memiliki efek perlindungan terhadap progesifitas nefritis lupus. Jalur NF- $\mathrm{BB}$ sangat penting dalam perkembangan lupus, jalur ini mengontrol ekspresi sejumlah gen proinflamasi, seperti iNOS maupun IL-17 yang kadarnya tinggi pada lupus dan berkorelasi dengan keparahan penyakitnya. N-Asetil Sistein (NAS) merupakan suatu senyawa yang mengandung tiol dengan efek antioksidan dan antiinflamasi. Efek antioksidan N-Asetil Sistein dapat terjadi secara langsung melalui interaksi dengan ROS elektrofilik maupun sebagai prekusor glutation, suatu antioksidan yang dapat melindungi sel dari stres oksidatif.

Penelitian iniakan membuktikan bahwaNAS akan berpengaruh terhadap peningkatan MMP9 dan glomerulosklerosis. Glomerulosklerosis maupun interstisial fibrosis akan menyebabkan fungsi filtrasi ginjal terganggu, sehingga sisa metabolisme seperti ureum, kreatinin terakumulasi dalam tubuh yang akan menyebabkan sindroma uremia. Glomerulosklerosis dan ROS akan menyebabkan kerusakan dan kebocoran sistem filtrasi yang berakibat terjadinya albuminuri. Albuminuri sesuai dengan hukum homeostasis merupakan bahan yang masih diperlukan oleh tubuh sehingga akan direabsorsi oleh sel tubulus, akibatnya sel tubulus harus bekerja keras dan hal ini merupakan suatu stresor sehingga sel tubulus mengekspresikan sitokin pro inflamasi (TNF- $\alpha 1$, IL-1 $\beta$, IL-6, IL-8 dan IL-17) dan TGF- $\beta 1$. Sitokin pro inflamasi tersebut akan lebih merusak sel-sel ginjal. Dengan demikian, suplemen antioksidan (NAS) pada pengobatan lupus nefritis mungkin dapat mencegah/mengurangi efek kerusakan ginjal serta keparahan lupus nefritis.

\section{METODE}

Penelitian ini merupakan penelitian eksperimental, terhadap mencit sebagai hewan coba. Rancangan eksperimental tanpa adanya pengukuran awal (pretest) tetapi hanya pengukuran 
akhir (post test) / post-test only control group design. Tempat laboratorium Fakultas Kedokteran Universitas Sebelas Maret, waktu (Januari-Mei 2016). Subjek penelitian adalah mencit, diperoleh dari Fakultas Kedokteran Hewan Universitas Gajah Mada. Kriteria inklusi : Mencit sehat, sub spesies Mus musculus galur Balb/C, umur 6-8 minggu, berat badan 20-30 gram. Kriteria eksklusi: Mencit mati saat penelitian. Berdasar rumus didapatkan jumlah sampel minimal adalah tujuh ekor. Dalam penelitian ini digunakan delapan ekor mencit untuk setiap kelompok observasinya, sehingga telah memenuhi batas minimal sampel.

Definisi operasional : Pemberian pristan pada mencit Balb/C menginduksi autoantibodi karakteristik lupus, N-Asetil Sistein diberikan secara peroral (sonde) dengan dosis $4,7 \mathrm{mg} / \mathrm{hari}$ (setara dengan dosis manusia $1.800 \mathrm{mg}$ ), ekspresi IL-17menggunakan pemeriksaan imunohistokimia dengan antibodi monoklonal terhadap IL-17. Cara ukur dinilai secara kuantitatif, visual dengan mikroskop cahaya pembesaran 400x terhadap 100 sel, yang terlihat dinetrofil sebagai yang mengekspresikan IL-17. Kemudian dihitung jumlah sel-sel tersebut yang imunoreaktif tercat coklat perak, pada membran sel. Jumlah semua sel immunoreaktif yang ditemukan kemudian dijumlahkan dan dimasukkan sebagai data. Skala data adalah rasio.

Data yang diperoleh akan dianalisis dengan langkah : analisis deskriptif, analisis normalitas dengan uji Shapiro-Wilk dan uji homogenitas varians dengan Levene's test, analisis komparasi. Data yang menyebar normal dan homogen, maka digunakan uji $\mathrm{F}$ Anova pada taraf kemaknaan $\alpha=0,05$ dilanjutkan dengan Least Significant Difference (LSD) post-hoc test Apabila data tidak normal dan homogen digunakan uji KruskalWallis, dilanjutkan uji Man Whitney.

\section{HASIL DAN PEMBAHASAN}

Penelitian ini dimaksudkan untuk mengetahui pengaruh terapi NAS terhadap ekspresi IL-17 pada glomerulus dan tubulus interstisialdan tingkat fibrosisinterstisialpada ginjal mencit nefritis lupus induksi pristan.Sebelum dilakukan uji hipotesis, terlebih dahulu dijelaskan deskripsi variabel penelitian yaituekspresi IL-17 dan tingkat fibrosisinterstisial pada kelompok kontrol, lupus nefritis, dan lupus nefritis+NAS.
Tabel 1. Deskripsi dan Uji Normalitas ekspresi IL-17 100 sel netrofil

\begin{tabular}{|c|c|c|c|}
\hline \multirow{2}{*}{ Kelonpolik } & \multirow{2}{*}{ 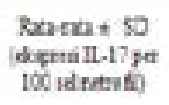 } & \multicolumn{2}{|c|}{ 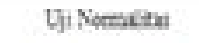 } \\
\hline & & sex.s\% & 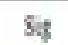 \\
\hline 1. Kastod & $7,5+1,6$ & $6,25 s$ & 0.250 \\
\hline 2 lepar tetiás & $2,8 \div 14,1$ & 6,934 & 8.597 \\
\hline 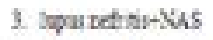 & $10,4+C, 8$ & 0,852 & 2,195 \\
\hline
\end{tabular}

Sumber: Data Primer 2015, diolah.

Keterangan: *Signifikan pada derajat signifikansi 5\%

Berdasarkan deskripsi variabel ekspresi IL$17 \mathrm{di}$ atas, nampak bahwa mencit yang diberikan perlakuan lupus nefritis memiliki rata-rata ekspresi IL-17 lebih tinggi dibandingkan pada kelompok kontrol. Pemberian NAS mampu menurunkan ekspresi IL-17. Perbedaan rata-rata ekspresi IL17 antar kelompok sampel itu dapat digambarkan sebagai berikut:

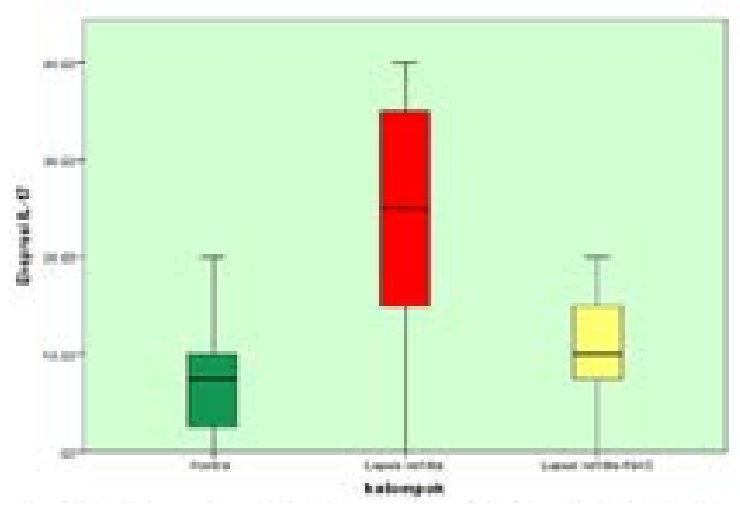

Gambar 5.1. Perbandingan Nilai Rata-rata ekspresi IL17 per 100 sel netrofil antar kelompok sampel

Deskripsi rinci nilai rata-rata dan standar deviasi serta hasil uji normalitas data masingmasing kelompok untuk variabel tingkat fibrosisinterstisialadalah sebagai berikut:

Tabel 2. Deskripsi dan Uji Normalitas Variabel tingkat fibrosisinterstisial

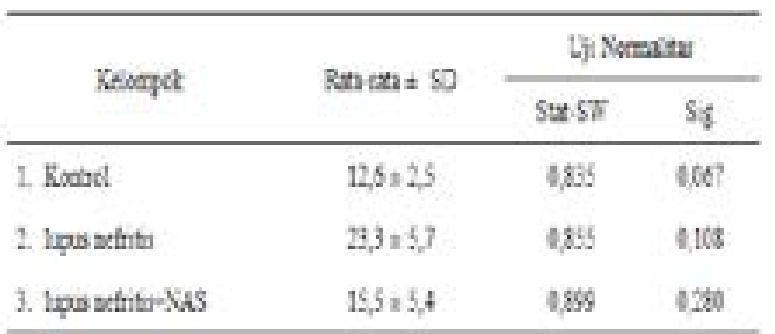

Sumber: Data Primer 2015, diolah.

Keterangan: *Signifikan pada derajat signifikansi 5\% 
Berdasarkan deskripsi variabel tingkat fibrosisinterstisial di atas, pemberian NAS menurunkan rata-rata tingkat fibrosisinterstisial dibandingkan pada kelompok lupus nefritis. Perbedaan rata-rata tingkat fibrosisinterstisial antar kelompok sampel itu dapat digambarkan sebagai berikut:

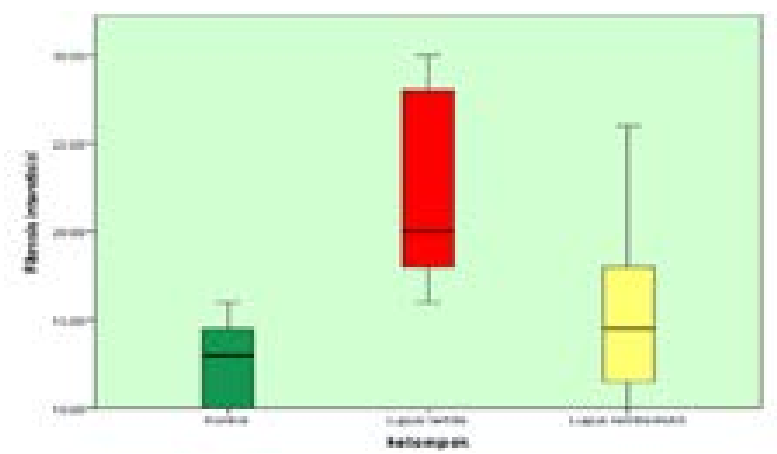

Gambar 5.2. Perbandingan Nilai Rata-rata tingkat fibrosisinterstisial antar kelompok sampel

Langkah pertama menguji variasi atau beda $\mathrm{k}$ rata-rata berdasarkan kelompok sampel untuk variabel IL-17. Distribusi data variabel IL17 semua kelompok sampel berdistribusi normal, maka pengujian variasi atau beda 3 rata-rata itu menggunakan ANOVA atau uji F. Hasil pengujian ANOVA untuk variabel IL-17 adalah sebagai berikut:

Tabel 3. Perbedaan rata-rata ekspresi IL-17 per 100 sel netrofil dalam kelompok sampel

\begin{tabular}{|c|c|c|c|c|c|}
\hline \multicolumn{2}{|c|}{ Kuctul } & \multicolumn{2}{|c|}{ upsetints } & \multicolumn{2}{|c|}{ hequ aefitat:Nas } \\
\hline $3 x+m$ & st & Ratara & $3 t$ & Rantza & $3 x$ \\
\hline 7,5 & 56 & 2,3 & 14. & 10,6 & 6,8 \\
\hline \multicolumn{2}{|c|}{$\operatorname{Nar} F=6.216$} & \multicolumn{2}{|c|}{ Sgzuflizs $=0,00 \theta^{\prime \prime}$} & \multicolumn{2}{|c|}{ šgrficas } \\
\hline
\end{tabular}

Sumber: Data Primer 2015, diolah.

Keterangan: **)Signifikan pada derajat signifikansi 1\%

Hasil analisis variasi atau beda 3rata-ratadi atas menunjukkan bahwa perbedaan 3 rata-rata variabel IL-17 tersebut menghasilkan nilai $\mathrm{F}$ hitung = 6,216 dengan tingkat signifikansi sebesar 0,008 yang berarti beda 3 rata-rata itu signifikan atau meyakinkan dengan derajat signifikansi $p<0,01$. Hal itu berarti beda rata-rata variabel IL-17 pada kelompok kontrol, lupus nefritis, dan lupus nefritis+NAS benar-benar berbeda secara meyakinkan. Jika dibandingkan dengan rata-rata IL-17 pada kelompok kontrol, kelompok lupus nefritis memiliki kecenderungan rata-rata IL-17 lebih tinggi (meningkat), kemudian rata-rata IL-17 pada kelompok lupus nefritis+NAS memiliki rata-rata lebih rendah dibandingkan kelompok lupus nefritis atau berarti ekspresi IL-17 itu dapat diturunkan dengan pemberian NAS.

Hasil penelusuran beda dua rata-rata variabel IL17 antar kelompok sampel dapat dijelaskan dengan tabel sebagai berikut:

Tabel 4. Perbedaan rata-rata ekspresi IL-17 per 100 sel netrofil antar kelompok sampel

\begin{tabular}{|c|c|c|}
\hline Kelserpete & Buda Rutaras & Sigrificesi \\
\hline Kestrat vs ipar sedmis & $-16,25$ & $0,010^{*}$ \\
\hline lipar aetras w zpar seftran-Xa5 & 13.13 & $0,042^{*}$ \\
\hline Koatrd is hup aefniti-Nas & 3,13 & 1000 \\
\hline
\end{tabular}

Sumber: Data Primer 2015, diolah.

Keterangan: **)Signifikan pada derajat signifikansi $1 \%$

Hasil analisis beda 2 rata-rata sampel independen menggunakan penelusuran Post Hoc Test Benferronidiatas menunjukkan bahwa uji terhadap variabel IL-17 antara kelompok Kontrol dan lupus nefritis signifikan pada derajat signifikansi sebesar $0,010(p<0,05)$. Hal itu dapat dikatakatan bahwa pada mencit kelompok lupus nefritis mempunyai rata-rata ekspresi IL-17 lebih tinggi (meningkat) secara meyakinkan dibandingkan kelompok kontrol. Setelah diberikan terapi NAS maka rata-rata ekspresi IL-17 lebih rendah (mengalami penurunan) dibandingkan pada kelompok lupus nefritis dengan tingkat signifikansi sebesar 0,042 $(\mathrm{p}<0,05)$.

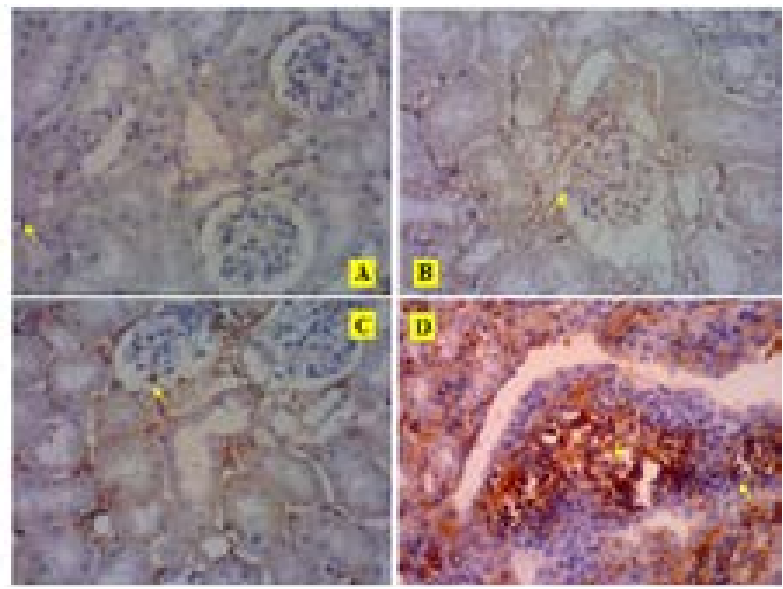

Gambar 5.3. Perbandingan gambaran protein IL-17 yang diekspresikan sel netrofil masing-masing kelompok 
Langkah kedua menguji variasi atau beda $\mathrm{k}$ rata-rata berdasarkan kelompok sampel untuk variabel tingkat fibrosisinterstisial. Distribusi data tingkat fibrosisinterstisialsecara keseluruhan masing-masing kelompok data berdistribusi normal, maka pengujian variasi atau beda 3 rata-rata itu menggunakan ANOVA atau uji F. Hasil pengujian ANOVA untuk variabel tingkat fibrosisinterstisial adalah sebagai berikut:

Tabel 5. Perbedaan rata-rata tingkat fibrosisinterstisial

\begin{tabular}{|c|c|c|c|c|c|}
\hline \multicolumn{2}{|c|}{ 'Bentri' } & \multicolumn{2}{|c|}{ Intertis } & \multicolumn{2}{|c|}{ hpos acinsexas } \\
\hline Rascas & Sed & Resens & $\$ 4$ & 30u-ma & \$21 \\
\hline 126 & 25 & 25) & 39 & 15.5 & 5. \\
\hline
\end{tabular}

Sumber: Data Primer 2015, diolah.

Keterangan: **)Signifikan pada derajat signifikansi $1 \%$

Hasil analisis variasi atau beda 3rataratadi atas menunjukkan bahwa perbedaan 3 ratarata variabel tingkat fibrosisinterstisial tersebut menghasilkan nilai $\mathrm{F}$ hitung $=8,627$ dengan tingkat signifikansi sebesar 0,002 yang berarti beda 3 ratarata itu signifikan atau meyakinkan dengan derajat signifikansi $p<0,01$. Hal itu berarti beda rata-rata variabel tingkat fibrosisinterstisialpada kelompok kontrol, lupus nefritis, dan lupus nefritis+NAS benar-benar berbeda secara meyakinkan. Jika dibandingkan dengan rata-rata tingkat fibrosisinterstisial padakelompok kontrol, kelompok lupus nefritis memiliki kecenderungan rata-rata tingkat fibrosisinterstisial lebih tinggi (meningkat), kemudian rata-rata tingkat fibrosisinterstisialpada kelompok lupus nefritis+NAS memiliki rata-rata lebih rendah (menurun) dibandingkan kelompok lupus nefritis atau berarti tingkat fibrosisinterstisial itu dapat diturunkan dengan pemberian NAS.

Tabel 5. Perbedaan rata-rata tingkat fibrosisinterstisial antar kelompok sampel

\begin{tabular}{|c|c|c|}
\hline Retenped & Bethenera & Sipficusi \\
\hline Reate 1 iqu whis & $-9,813$ & $0,000^{*}$ \\
\hline 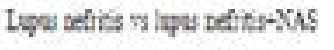 & 6,75 & $\left(,, 9 M^{*}\right.$ \\
\hline 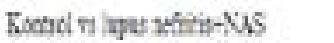 & 288 & $0,721^{\circ}$ \\
\hline
\end{tabular}

Sumber: Data Primer 2015, diolah.

Keterangan: *)Signifikan pada derajat signifikansi 5\%

**)Signifikan pada derajat signifikansi $1 \%$
Hasil analisis beda 2 rata-rata sampel independen menggunakan penelusuran Post Hoc Test Benferronidiatas menunjukkan bahwa uji terhadap variabel tingkat fibrosisinterstisial antara kelompok Kontrol dan lupus nefritis signifikan pada derajat signifikansi sebesar $0,002(\mathrm{p}<0,001)$.
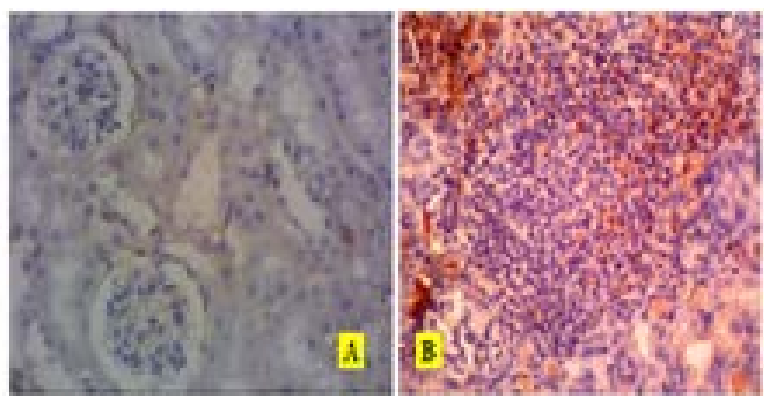

Gambar 5.4. Perbandingan gambaran tingkat fibrosisinterstisial.

A: ginjal normal; B: fibrosis dan inflamasi interstisial (Pewarnaan Hematoksilineozin: pembesaran 1000x-Olympus BX 50 Model BX-50F-3 Pentax Optio 230

Digital Camera 2.0 Megapixel)

Berdasarkan prinsip ontologi, injeksi Pristan pada mencit Balb/C secara intraperitoneal dapat mengembangkan respons inflamasi lokal (lipogranuloma) dan artritis erosif menyerupai reumatoid artritis (RA) dan juga dapat menginduksi produksi autoantibodi dan manifestasi klinis SLE. Proses ini sesuai dengan initial stage (Incubation period/Sub clinical) dalam tahapan proses penyakit.

Injeksi pristan i.p. akan mengaktivasi $\mathrm{NFk} \beta$ dan p38 MAPK sehingga terjadi peningkatan produksi TGF-b. TGF-bakan merangsang sel target, yaitu sel fibroblas, sel mesangial, podosit, sel tubulus dan sel endotel. Aktivasi sel-sel target ini akan memicu terbentuknya ECM. Sel fibroblas akan mengekspresikan kolagen tipe-I dan akhirnya menyebabkan terjadinya fibrosis interstisial pada ginjal (Purwanto, 2010; Loeffler dan Wolf, 2013). Proses ini sesuai dengan tahap emergence stage dalam tahapan proses penyakit (Purwanto, 2010).

Pemberian kombinasi NAS pada mencit lupus nefritis pada penelitian ini, NAS berperan sebagai anti ROS, sehingga kerusakan sel (debris) berkurang, akibatnya rangsangan terhadap makrofag lewat TLR-4 dan TLR-9 berkurang pula. Akibatnya ekspresi TGF- $\beta 1$ oleh makrofag juga berkurang, sebaliknya ekspresi MMP9 meningkat. Kondisi tersebut akan berperan dalam memperbaiki keadaan imbalance tersebut. Berdasarkan pendekatan prinsip epistomologi, 
penelitian ini ekspresi IL-17di netrofil ginjal pada kelompok mencit yang diinduksi pristan sebagai agen nefrotoksik terlihat lebih tinggi daripada mencit normal sebagai kontrol. Peningkatan ekspresi IL-17 terjadi karena pemberian pristan akan menyebabkan (a) stimulasi mediator inflamasi, (b) peningkatan produksi autoantibodi, (c) peningkatan deposisi kompleks imun di glomerulus, (d) peningkatan TGF- $\beta 1$, (e) meningkatknya imunogenisitas dan (f) apoptosis yang meningkat (Reeves dkk., 2009; Vahed dkk., 2015).

Berdasarkan prinsip axiologi, secara keseluruhan manfaat hasil penelitian ini adalah kombinasi lupus nefritis+NAS dapat mencegah/ mengurangi efek nefrotoksik pada ginjal. NAS merupakan suatu senyawa yang mengandung tiol dengan efek antioksidan dan antiinflamasi. Efekantioksidan NAS dapat terjadi secara langsung melalui interaksi dengan ROS elektrofilik maupun sebagai prekusor glutation, suatu antioksidan yang dapat melindungi sel dari stres oksidatif (De Backer dkk., 2013).Stres oksidatif terjadi ketika produksi ROS berlebihan melebihi kapasitas metabolisme dari sistem pertahanan antioksidan, sehingga mengakibatkan kerusakan jaringan ginjal. Terapi NAS akan menghambat ekspresi dan aktivitas enzim antioksidan seperti SOD, katalase dan glutation peroksidase. Dengan demikian, suplemen NAS pada lupus nefritis dapat mengurangi efek nefrotoksik pada ginjal, melalui penurunan ekspresi IL-17 dan derajat fibrosis interstisial.

\section{SIMPULAN}

N-Asetil Sistein terbukti menurunkan ekspresi interleukin 17 dan menurunkan fibrosis interstisial pada mencit lupus nefritis induksi pristan.

\section{DAFTAR PUSTAKA}

De Backer J, Vos W, Van Holsbeke C, Vinchurkar S, Claes R, Parizel PM, De Backer W. 2013. Effect of high-dose $\mathrm{N}$-acetylcysteine on airway geometry, inflammation, and oxidative stress in COPD patients. Int J Chron Obstruct Pulmon Dis. 8:569-79Isbagio H, Albar Z, Kasjmir YI, Setyohadi B. 2006. Lupus Eritematosus Sistemik. Buku Ajar Ilmu Penyakit Dalam Jilid II, Edisi IV, hal: 1224-1230.

Lan HY. 2011. Diverse roles of TGF $\beta /$ Smads in renal fibrosis and inflammation. Int J Biol Sci. 7(7) : 1056-67.

Loeffler I, Wolf G. 2013. Transforming growth factor- $\beta$ and the progression of renal disease. Nephrol Dial Transplant 0: 1-9.

Li M, Gao W, Ma J, Zhu Y, Li X. 2015. Early-stage lupus nephritis treated with N-acetylcysteine: A report of two cases. Exp Ther Med. 10(2):689-692.

Motazed R, Colville-Nash P, Kwan JTC, Dockrell MEC. 2008. BMP-7 and Proximal Tubule Epithelial Cells: Activation of Multiple Signaling Pathways Reveals a Novel Anti-fibrotic Mechanism. Pharmaceutical Research 25(10):2440-2446.

Purwanto B. 2010. Kajian ekspresi tgf- $\beta 1$, mmp-9, kolagen tipe-I, kolagen tipe-IV, glomerulosklerosis, interstisial fibrosis, albuminuri pada kejadian nefrotoksik doxorubicin dan nefroprotektif pentoxifylin dengan hewan coba mencit galur swiss jantan. Disertasi. Program Pascasarjana. Universitas Airlangga. Surabaya

Reeves WH, Lee PY, Weinstein JS, Satoh M, Lu L. 2009. Induction of autoimmunity by pristane and other naturally occurring hydrocarbons. Trends Immunol 30(9):455-64.

Tan TK, Zheng G, Hsu TT, Wang Y, Lee VW, Tian X. 2010. Macrophage matrix metalloproteinase-9 mediates epithelial-mesenchymal transition in vitro in murine renal tubular cells. Am J Pathol. 176(3):1256-70.

Vahed SZ, Ardalan M, Samadi N, Omidi Y. 2015.Pharmacogenetics and drug-induced nephrotoxicity in 
renal transplant recipients. Bioimpacts. 5(1): 45-54.

Wang Y, Ito S, Chino Y, Goto D, Matsumoto I, Murata H. 2010. Laser microdissection-based analysis of cytokine balance in the kidneys of patients with lupus nephritis.Clin Exp Immunol. 159(1):110.

Ward MM. 2014. Recent Clinical Trials In Lupus Nephritis. Rheum Dis Clin North Am. 40(3): 519-535. 